\title{
Blood metabolites of extensively reared Croatian multi-coloured goats during early lactation and early gravidity
}

\author{
Lada Radin ${ }^{1}$, Ana Shek Vugrovečki ${ }^{1}$, Jadranka Pejaković Hlede ${ }^{1}$, \\ Silvijo Vince ${ }^{2}$, Iva Ljubičićc ${ }^{3}$, and Miljenko Šimpraga ${ }^{1 *}$
}

${ }^{1}$ Department of Physiology and Radiobiology, Faculty of Veterinary Medicine, University of Zagreb, Zagreb, Croatia

${ }^{2}$ Clinic of Obstetrics and Reproduction, Faculty of Veterinary Medicine, University of Zagreb, Zagreb, Croatia

${ }^{3}$ Department of Karst Agriculture, Polytechnic "Marko Marulic', Knin, Croatia

RADIN, L., A. SHEK VUGROVEČKI, J. PEJAKOVIĆ HLEDE, S. VINCE, I. LJUBIČIĆ, M. ŠIMPRAGA: Blood metabolites of extensively reared Croatian multi-coloured goats during early lactation and early gravidity. Vet. arhiv 87, 273280, 2017.

\section{ABSTRACT}

Goat breeding has been one of the most important activities of the rural population in Dalmatian Zagora for decades. The predominant breed was, and still is, the Croatian coloured goat, bred almost exclusively for meat. Extensive farming is currently a dominant farming system with some flocks being bred under organic conditions. In this research we monitored an organic flock in the area of Dinara Mountain during one season. Blood samples were randomly collected from 80 does on two occasions: in March in their early lactation and in October in their early gravidity, and were analysed for the most common biochemical parameters (glucose, urea, bilirubin, total proteins, albumin, triglycerides, cholesterol, aspartate aminotransferase (AST), gamma-glutamyl transferase (GGT) and two parameters of metabolic profile (non-esterified fatty acids (NEFA), $\beta$-hydroxybutyrate (BHB)). Significant differences were found between all of the parameters, except BHB and AST. The obtained results from multi-coloured goats may represent a contribution to a better understanding of metabolic processes during early lactation and early gravidity in indigenous Croatian goats.

Key words: goats, blood biomarkers, Croatian multi-coloured goat

\section{Introduction}

Goat breeding in Dalmatian Zagora was and still is one of the most important animal farming activities for the inhabitants of these rural areas of Croatia (PRPIĆ and MIOČ, 2015). The predominant breed in the Mediterranean part of Croatia (Dalmatian area) is the

\footnotetext{
*Corresponding author:

Prof. Miljenko Šimpraga, PhD, Department of Physiology and Radiobiology, Faculty of Veterinary Medicine, University of Zagreb, Heinzelova 55, 10000 Zagreb, Croatia, Phone: +385 12390 170; E-mail: miljenko_simpraga@vef.hr
} 
Croatian multi-coloured goat, bred almost exclusively for meat. Extensive farming is the dominant farming system, while some farmers have recently started organic production. Although indigenous breeds are usually regarded as primitive, they have had a profound economic and social impact over the centuries in this rural region, where the harsh topography is unsuitable for most other agricultural uses (MIOČ et al., 2012).

Blood biochemical parameters are a source of objective and useful information indispensable in assessing the physiological, metabolic, health, nutritional status, welfare and productivity of animals. They are useful in diagnosing diseases and determining their prognosis, as well as in preventive programs. Comparison of biochemical results and physiological ranges is complex, because values depend on many factors, such as: breed, sex, age, nutrition, physiological conditions (pregnancy and lactation), illness and seasonal variations (YOKUS et al., 2006). Using reference intervals available from textbooks (KANEKO et al., 2008) has been shown to be inappropriate considering the large number (much more than the expected 5\%) of clinically healthy animals falling outside the published intervals (VOJTA et al., 2011). Physiological properties of Croatian indigenous sheep and goat breeds were investigated in our previous studies, and the need for specific reference intervals was determined (VOJTA et al., 2011; SHEK-VUGROVEČKI et al., 2012; ŠIMPRAGA et al., 2013).

Meeting the nutrient requirements for grazing and browsing animals is challenging, and can lead to metabolic disorders (EŞKI et al., 2015), especially in early spring when the dry matter content of pasture grasses, plant species and herbage is very low. The most valuable parameters for assessment of the ruminants' energy status are plasma concentrations of non-esterified fatty acids (NEFA), triglycerides and $\beta$-hydroxybutirate (BHB) (FERNANDEZ et al., 2007) for which there are no reference values for goats in the textbooks (KANEKO et al., 2008). Differences between goats of different genotypes may indicate different physiological adaptation mechanisms under the same nutritional conditions, especially during pregnancy (CASTAGNINO et al., 2015).

Since the data describing biochemical parameters in Croatian indigenous goat breeds are scarce, the aim of the present study was to investigate the variations in blood biochemical parameters in two periods of a doe's life: postpartum and early gravidity. The obtained results may represent a contribution to a better understanding of the metabolism of energy and proteins in extensively bred combined breed goats for diagnostic purposes.

\section{Materials and methods}

Animals, husbandry, nutrition. The study was carried out on a small organic commercial farm of Croatian coloured goats in the Dinara Mountain area. The group comprised randomly selected 80 females (does). The animals were kept indoors only during extreme winter weather conditions. They browsed the mountain pastures all day 


\section{Radin et al.: Blood metabolites of Croatian multi-coloured goat}

long, except during the winter. The goats were 1.5 to 7 years old and had an average body weight of $35 \pm 5.6 \mathrm{~kg}$ (mean $\pm \mathrm{SD}$ ). The experiment was carried out in two phases coinciding with two seasons of the year - spring (March) and late autumn (October). During the spring phases all the goats were in early lactation and during the winter phase of the experiment the does were in the first third of gravidity, as confirmed by the owner. The animals were monitored throughout the year by the local veterinarian and were provided similar management during the experimental period. Water was available ad libitum for the animals at all times. Hay was only consumed by the goats at times when they could not be in the pasture because of snow or bad weather conditions. There was no supplementary feeding of goats with concentrated animal feed. The mean temperature and humidity values for the area in March and October are shown in Table 1. There were no extreme variations in temperature or humidity during the time of the experiment.

Sample collection and analytical procedures. Blood samples were collected from randomly selected goats by jugular venipuncture between 9.00 and 11.00 a.m. once in March and for the second time in October.

Samples were collected into evacuated tubes $\left(\right.$ Vacutainer $\left.^{\circledR}\right)$ without anticoagulant, kept in a cool place and centrifuged within 3 hours of blood collection at $1500 \mathrm{~g}$ and for 15 $\min$. The harvested serum was frozen and stored at $-70^{\circ} \mathrm{C}$ until the time of analysis. The concentrations of $\beta$-hydroxybutyrate (BHB), non-esterified fatty acids (NEFA) in serum samples were determined using kits from Randox Laboratories LTD, Ardmore, UK, on SABA 18 (AMS, Italy), while reagents from Herbos, Croatia were used for albumin, glucose, triglycerides, aspartate amino transferase (AST), gamma-glutamyl transferase (GGT) and urea concentrations on the same instrument, SABA 18 (AMS, Italy).

Statistical analysis. Statistical analyses were performed using SAS 9.3 software (2002-2010 SAS Institute Inc., Cary, NC, USA). The mixed model (PROC MIXED) with a repeated measure statement was used to analyse the blood metabolic parameters. The goat ID number was the subject variable for which repeated measurements were taken. Results are expressed as least square means \pm standard error ( $\mathrm{LSM} \pm \mathrm{SE}$ ). The level of statistical significance was set at $\mathrm{P}<0.05$.

\section{Results}

Blood biochemical parameters. Results of blood biochemical parameters are presented in Table 2. All the metabolic parameters remained within the reference limits for the available parameters (KANEKO et al., 2008) at both points in time, except for the levels of total protein and total bilirubin, which were found to be higher than the reference values, and AST activity that was lower than the reference values at both measuring points. 


\section{Radin et al.: Blood metabolites of Croatian multi-coloured goat}

Statistically significant differences $(\mathrm{P}<0.01)$ were found for all parameters between the March and October samplings, except for concentrations of BHB and AST. The values for NEFA and urea were significantly higher $(\mathrm{P}<0.0001)$ in March than in October, while albumin, total protein, triglycerides, GGT and total bilirubin values were significantly lower $(\mathrm{P}<0.0001)$ in March than in October.

Table 1 . Mean daily temperature $\left({ }^{\circ} \mathrm{C} \pm \mathrm{SD}\right)$ and humidity $(\%) \pm \mathrm{SD}$ for the months of March and October from the Meteorological Station, Knin, Croatia

\begin{tabular}{|l|c|c|}
\hline & Mean temperature $\left({ }^{\circ} \mathrm{C}\right) \pm \mathrm{SD}$ & Air humidity $(\%) \pm \mathrm{SD}$ \\
\hline March & $8.3 \pm 2.6$ & $61 \pm 15$ \\
\hline October & $12.9 \pm 4.1$ & $64 \pm 14$ \\
\hline
\end{tabular}

Table 2. Least square means ( $\mathrm{LSM} \pm \mathrm{SE}$ ) of blood parameters of Croatian coloured goat in March and October with comparison to reference values (KANEKO et al., 2008).

\begin{tabular}{|c|c|c|c|c|}
\hline & & & \multirow[b]{2}{*}{ Significance } & \multirow{2}{*}{$\begin{array}{l}\text { Reference interval for goats } \\
\text { (Kaneko et al., 2008) }\end{array}$} \\
\hline & March & October & & \\
\hline NEFA (mmol/L) & $0.68 \pm 0.04$ & $0.33 \pm 0.04$ & $<0.0001$ & - \\
\hline $\mathrm{BHB}(\mathrm{mmol} / \mathrm{L})$ & $0.4 \pm 0.03$ & $0.4 \pm 0.03$ & n. s. & - \\
\hline Glucose $(\mathrm{mmol} / \mathrm{L})$ & $3.43 \pm 0.06$ & $3.42 \pm 0.06$ & n. s. & $2.78-4.16$ \\
\hline Triglycerides $(\mathrm{mmol} / \mathrm{L})$ & $0.27 \pm 0.01$ & $0.43 \pm 0.01$ & $<0.0001$ & - \\
\hline Albumin $(\mathrm{g} / \mathrm{L})$ & $37.6 \pm 0.27$ & $40.42 \pm 0.27$ & $<0.0001$ & $27-39$ \\
\hline Total protein $(\mathrm{g} / \mathrm{L})$ & $85.23 \pm 0.86$ & $102.73 \pm 0.86$ & $<0.0001$ & $64-70$ \\
\hline GGT (U/L) & $35.43 \pm 0.97$ & $42.28 \pm 0.97$ & $<0.0001$ & $20-56$ \\
\hline AST (U/L) & $84.02 \pm 2.25$ & $83.95 \pm 2.25$ & n. s. & $167-513$ \\
\hline Urea $(\mathrm{mmol} / \mathrm{L})$ & $6.73 \pm 0.16$ & $5.65 \pm 0.16$ & $<0.0001$ & $3.57-7.14$ \\
\hline Total bilirubin $(\mu \mathrm{mol} / \mathrm{L})$ & $5.77 \pm 0.24$ & $7.27 \pm 0.25$ & 0.0001 & $0-1.71$ \\
\hline Cholesterol $(\mathrm{mmol} / \mathrm{L})$ & $2.11 \pm 0.04$ & $2.25 \pm 0.04$ & 0.0025 & $2.07-3.37$ \\
\hline
\end{tabular}

n.s.- statistically non-significant

\section{Discussion}

Together with NEFA concentrations, levels of blood ketones are also considered useful for determination of energy status in ruminants, while hypoglycaemia is recognized as an indication of low energy intake (FERNÁNDEZ et al., 2007; DORÉ et al., 2015). To our knowledge, there are no reference values for NEFA in goats; KANEKO et al. (2008) mention a very wide range for cows $(0.378-3.78 \mathrm{mmol} / \mathrm{L})$, but none for sheep and goats. NEFA values in this research were significantly higher $(\mathrm{P}<0.0001)$ in early lactation 


\section{Radin et al.: Blood metabolites of Croatian multi-coloured goat}

(March) than at the beginning of gravidity (October), which is consistent with results for sheep, goats and cows published by various authors (EŞKI et al., 2015; RADIN et al., 2015). This rise corresponds to physiological adaptation to gravidity and the beginning of lactation. No values were higher than $1 \mathrm{mmol} / \mathrm{L}$, which might signify that the animals were not experiencing any negative energy balance.

A BHB blood threshold of $\geq 0.86 \mathrm{mmol} / \mathrm{L}$ was proposed for dairy goats by BANI ISMAIL et al. (2008) as an acceptable value to define hyperketonaemia to predict pregnancy toxaemia, and in a study by DORÉ et al. (2015) the hyperketonaemia definition based on pregnancy toxaemia varied between $\geq 0.4$ and $\geq 0.9 \mathrm{mmol} / \mathrm{L}$ during the last 5 weeks prepartum. For goats in this research BHB values were consistent at around $0.4 \mathrm{mmol} / \mathrm{L}$ $( \pm 0.01 \mathrm{mmol} / \mathrm{L})$ in both sampling periods. The goats showed no signs of periparturient metabolic disorders.

Urea in the blood is an important indicator of the supply of nitrogen and energy through meals. A decrease comes with a deficit of protein in the diet, especially in a combined deficit of energy and protein. An increase in urea in the blood is seen with a surplus of protein in the diet, with an absolute or relative lack of energy (RADOVIĆ et al., 2011). Urea blood levels may indicate short term metabolic changes and are used together with serum total protein and albumin levels (ZOBEL et al., 2015). As seen in our research, TP and ALB levels were lower in the early lactation period while urea was higher in the early pregnancy period, as found by IRIADAM et al. (2007). Since there was no feed supplementation for the kidding goats, there might have been an enhanced need for protein consumption, both due to lactation onset and the growing foetus' needs in the last trimester of pregnancy (ANTUNOVIĆ et al., 2011; CASTAGNINO et al., 2015). Protein levels were altogether higher than the reference values for goats (KANEKO et al., 2008), which might be a breed trait, as seen among other indigenous small ruminant breeds (ŠIMPRAGA et al., 2013; ANTUNOVIĆ et al., 2015). The average birth weight of Croatian multi-coloured breed kids $(2.28 \mathrm{~kg} \pm 0.72$; mean $\pm \mathrm{SD})$ is significantly lower than that determined for other breeds used in intensive meat and milk production systems. Apart from the genotype, the lower birth weight of Croatian multi-coloured goat kids may be ascribed to the breeding system used, but mostly to poor feeding conditions (MIOČ et al., 2011). That fact is consistent with lower values of TP and ALB found at the beginning of lactation, and elevated levels of urea signifying enhanced protein catabolism in the final third of gestation in sheep and goats (CASTAGNINO et al., 2015; PICCIONE et al., 2009).

Triglyceride levels were lower at the beginning of lactation than at the beginning of gestation, as found by many authors for ruminants, probably as an effect of hormonally regulated lipolysis (KARAPEHLIVAN et al., 2007; PICCIONE et al., 2009). Elevation of cholesterol during lactation and pregnancy, as found in this research, is thought to be a sign of its increased production through stimulation by oestrogen (IRIADAM et al., 


\section{Radin et al.: Blood metabolites of Croatian multi-coloured goat}

2007). The AST activity found in this research in both periods was significantly lower than the literature reference values (KANEKO et al., 2008), and according to PICCIONE et al. (2010) for Girgentana goats. The AST activity did not alter significantly in the two research periods, as found for Saanen and Boer goats by DJURIČIĆ et al. (2011). Unlike ANTUNOVIĆ et al. (2011) the total bilirubin levels were higher during early lactation than in early pregnancy, and altogether higher than the reference values found in the literature (KANEKO et al., 2008), as mentioned by LEPHERD et al. (2009) for Merino ewes. The elevated levels of bilirubin in both periods of this research could signify a greater burden on liver hepatocytes due to inadequate feed (RADOVIĆ et al., 2011).

The obtained results for multi-coloured goats may represent a contribution to a better understanding of metabolic processes during early lactation and early gravidity in combined breed goats, and for diagnostic purposes.

\section{Conflict of interest statement}

None of the authors of this paper has a financial or personal relationship with other people or organizations that could inappropriately influence or bias the content of the paper. This research was partially funded from a grant by the Ministry of Fisheries, Agriculture and Rural Development, No. 4-7106.

\section{References}

ANTUNOVIĆ, Z., J. NOVOSELEC, H. SAUERWEIN, M. ŠPERANDA, M. VEGARA, V. PAVIĆ (2011): Blood metabolic profile and some of hormones concentration in ewes during different physiological status. Bulg. J. Agric. Sci. 17, 687-695.

ANTUNOVIĆ, Z., B. MARKOVIĆ, J. NOVOSELEC, M. ŠPERANDA, M. MARKOVIĆ, B. MIOČ, M. DJIDARA, D. RADONJIĆ (2015): Blood Metabolic profile and oxidative status of endangered Mediterranean sheep breeds during pregnancy. Bulg. J. Agric. Sci., 21, 655-661.

BANI ISMAIL, Z. A., A. M. AL-MAJALI, F. AMIREH, O. F. AL-RAWASHDEH (2008): Metabolic profile in goat does in late pregnancy with and without subclinical pregnancy toxaemia. Vet. Clin. Pathol. 37, 434 - 437.

CASTAGNINO, D., C. J. HÄRTER, A. R. RIVERA, L. D. de LIMA, H. G. DE OLIVEIRA SILVA, B. BIAGIOLI, K. T. DE RESENDE, I. A. M. DE ALMEIDA TEIXEIRA (2015): Changes in maternal body composition and metabolism of dairy goats during pregnancy. Rev. Bras. Zootecn. 44, 92-102.

DJURIČIĆ, D., T. DOBRANIĆ, J. GRIZELJ, D. GRAČNER, I. HARAPIN, D. STANIN, I. FOLNOŽIĆ, I. GETZ, D. CVITKOVIĆ, M. SAMARDŽIJA (2011): Concentrations of total proteins and albumins, and AST, AP, CK and GGT activities in the blood serum boer and saanen goats during puerperium. Reprod. Domest. Anim. 46, 674-677.

DORÉ, V., J. DUBUC, A. M. BÉLANGER, S. BUCZINSKI (2015): Definition of prepartum hyperketonemia in dairy goats. J. Dairy Sci. 98, 4535-4543. 


\section{Radin et al.: Blood metabolites of Croatian multi-coloured goat}

EŞKI, F., I. TAŞAL, M. A. KARSLI, S. ŞENDAĞ, B. A. USLU, H. WAGNER, A. WEHREND (2015): Concentrations of NEFA, ß-HBA, triglycerides, and certain blood metabolites in healthy colored Angora goats during the peripartum period. Turk. J. Vet. Anim. 39, 401-405.

FERNÁNDEZ, J. R., E. RAMOS, G. de LA TORRE, R. HERMOSO, F. GIL EXTREMERA, M. R. SANZ SAMPELAYO (2007): Blood metabolites as indicators of energy status in goats. In: Advanced nutrition and feeding strategies to improve sheep and goat. Zaragoza: CIHEAM, (Priolo A., Biondi L., Ben Salem H., Morand-Fehr P., Eds.), Options Méditerranéennes: Série A. n. 74). p. 451-455

IRIADAM, M. (2007): Variation in certain hematological and biochemical parameters during the peri-partum period in Kilis does. Small Rum. Res. 73, 54-57.

KANEKO, J. J., J. W. HARVEY, M. L. BRUSS (2008): Clinical Biochemistry of Domestic Animals, $6^{\text {th }}$ ed. Academic Press, London.

KARAPEHLIVAN, M., E. ATAKISI, O. ATAKISI, R. YUCAYURT, S. M. PANCARCI (2007): Blood biochemical parameters during the lactation and dry period in Tuj ewes. Small Rum. Res. 73, 267-271.

LEPHERD, M. L., P. J. CANFIELD, G. B. HUNT, K. L. BOSWARD (2009): Haematological, biochemical and selected acute phase protein reference intervals for weaned female Merino lambs. Aust. Vet. J. 87, 5-11.

MIOČ, B., Z. BARAĆ, V. PAVIĆ, Z. PRPIĆ, D. MULC, M. ŠPEHAR (2012): Goat breeding programme in Republic of Croatia, Hrvatski savez uzgajivača ovaca i koza, Zagreb.

MIOČ, B., V. SUŠIĆ, Z. ANTUNOVIĆ, Z. PRPIĆ, I. VNUČEC, A. KASAP (2011): Study on birth weight and pre-weaning growth of Croatian multicolored goat kids. Vet. arhiv 81, 339-347.

PICCIONE, G., G. CAOLA, C. GIANNETTO, F. GRASSO, S. CALANNI RUNZO, A. ZUMBO, P. PENNISI (2009): Selected biochemical serum parameters in ewes during pregnancy, postparturition, lactation and dry period. Anim. Sci. Pap. Rep. 27, 321-330.

PICCIONE, G., S. CASELLA, L. LUTRI, I. VAZZANA, V. FERRANTELLI, G. CAOLA (2010): Reference values for some haematological, haematochemical, and electrophoretic parameters in the girgentana goat. Turk. J. Vet. Anim. 34, 197-204.

PRPIĆ, Z., B. MIOČ (2015): Mogućnosti uzgoja koza na području Dalmatinske zagore. Zbornik radova: Gospodarske mogućnosti Zagore i oblici njihova optimalnog iskorištavanja. (Matas, M., A. Rako, Eds.), Split: Kulturni sabor Zagore i Institut za jadranske kulture i melioraciju krša - Split, pp. 29-40.

RADIN, L., M. ŠIMPRAGA, S. VINCE, A. KOSTELIĆ, S. MILINKOVIĆ-TUR (2015): Metabolic and oxidative status of Saanen goats of different parity during the peripartum period. J. Dairy Res. 82, 426-433.

RADOVIĆ, B., S. JOTANOVIĆ, Đ. SAVIĆ, A. NITOVSKI (2011): Blood biochemical parameters of Simmental cows in different phases of reproductive cycle. Veterinarski glasnik 65, 191-201.

SHEK-VUGROVEČKI, A., L. RADIN, J. PEJAKOVIĆ, K. SINKOVIĆ, M. ŠIMPRAGA (2012): Current aspects and recommendations in health management of organic sheep and goat farming in karst areas. In: Animal Farming and Environmental Interactions in the Mediterranean Region 


\section{Radin et al.: Blood metabolites of Croatian multi-coloured goat}

(Rogošić J., A. Rosati, D. Gabina, Eds.). EAAP publication No. 131 Wageningen Academic Publishers, Wageningen, Netherlands. pp. 121-125.

ŠIMPRAGA, M., T. ŠMUC, K. MATANOVIĆ, L. RADIN, A. SHEK-VUGROVEČKI, I. LJUBIČIĆ, A. VOJTA (2013): Reference intervals for organically raised sheep: Effects of breed, location and season on hematological and biochemical parameters. Small Rum. Res. 112, 1-6.

VOJTA, A., A. SHEK-VUGROVEČKI, L. RADIN, M. EFENDIĆ, J. PEJAKOVIĆ, M. ŠIMPRAGA (2011): Hematological and biochemical reference intervals in Dalmatian pramenka sheep estimated from reduced sample size by bootstrap resampling. Vet. arhiv 81, 25-33.

YOKUS, B., D. U. CAKIR, Z. KANAY, G. TOPRAK, E. UYSAL (2006): Effects of seasonal and physiological variations on the serum chemistry, vitamins and thyroid hormone concentrations in sheep. J. Vet. Med. A. 53, 271-276.

ZOBEL, G., D. M. WEARY, K. LESLIE, N. CHAPINAL, M. A. G. VON KEYSERLINGK (2015): Technical note: Validation of data loggers for recording lying behavior in dairy goats. J. Dairy Sci. 98, 1082-1089.

Received: 23 December 2015

Accepted: 13 July 2016

\section{RADIN, L, A. SHEK VUGROVEČKI, J. PEJAKOVIĆ HLEDE, S. VINCE, I. LJUBIĆIĆ, M. ŠIMPRAGA: Biokemijski pokazatelji u krvi ekstenzivno uzgajane hrvatske šarene koze u vrijeme rane gravidnosti i laktacije. Vet. arhiv 87, 273-280, 2017.}

\section{SAŽETAK}

Uzgoj koza desetljećima je bio jedna od najvažnijih aktivnosti ruralnog stanovništva Dalmatinske zagore. Dominantna pasmina je bila, i još uvijek jest, hrvatska šarena koza, koja se uzgaja gotovo isključivo za meso. Ekstenzivno stočarenje trenutno je prevladavajući način uzgoja u tom području, s nekolicinom stada koja se uzgajaju pod ekološkim uvjetima. U ovom istraživanju pratili smo ekološko stado hrvatske šarene koze na području planine Dinare tijekom jedne sezone. Uzorci krvi prikupljeni su od 80 koza u dva navrata, u ožujku u ranoj laktaciji te u listopadu u ranoj gravidnosti. Analizirani su najvažniji biokemijski pokazatelji (glukoza, ureja, bilirubin, ukupni proteini, albumin, trigliceridi, kolesterol, AST, GGT) i dva pokazatelja metaboličkog profila (BHB, NEFA). Ustanovljene su značajne razlike među svim pokazateljima osim BHB i AST. Dobiveni rezultati za hrvatsku šarenu kozu predstavljaju doprinos boljem razumijevanju metaboličkih procesa tijekom rane laktacije i početkom gravidnosti u autohtonih hrvatskih koza.

Ključne riječi: koze, hrvatska šarena koza, biokemijski pokazatelji 